\title{
Maggots in the management of ulcer care
}

\section{Shawnee Munro, Abubakar Hadid, Muhammad Javaid Hameed Rahmani}

Correspondence to Dr Muhammad Javaid Hameed Rahmani, m.rahmani3@nhs.net

Accepted 6 May 2017

\section{DESCRIPTION}

An elderly man was admitted to the hospital with right leg mixed aetiology ulcers and superadded cellulitis, which had been unresponsive to several weeks of oral

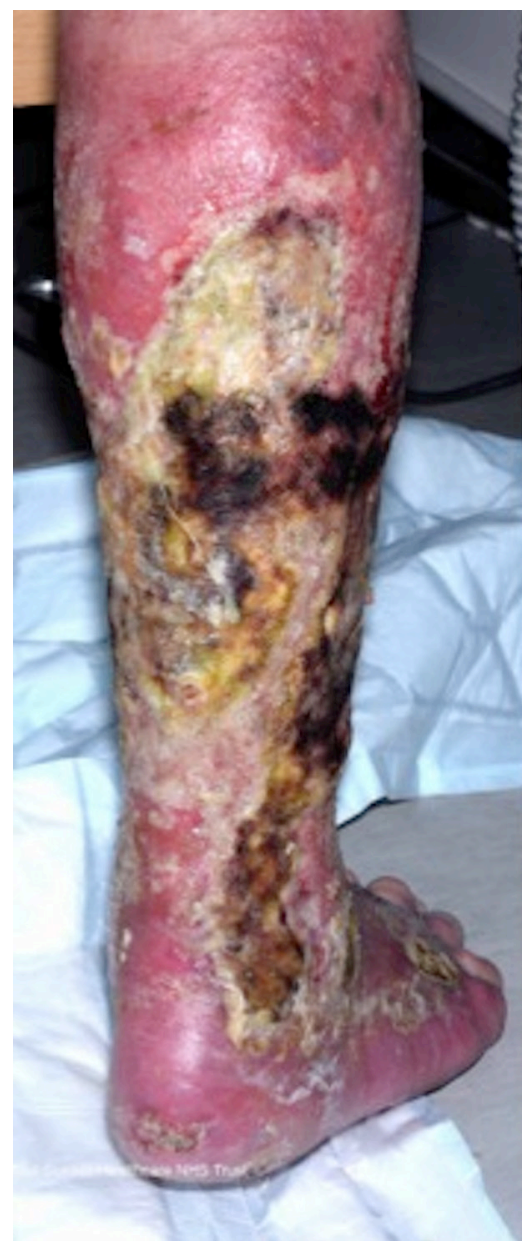

Figure 1 Image showing right leg mixed aetiology ulcers and superadded cellulitis.

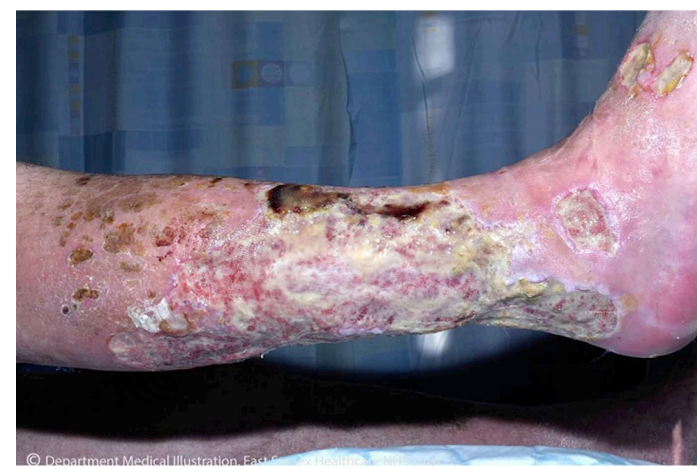

Figure 2 Image showing right leg postsurgical debridement therapy.

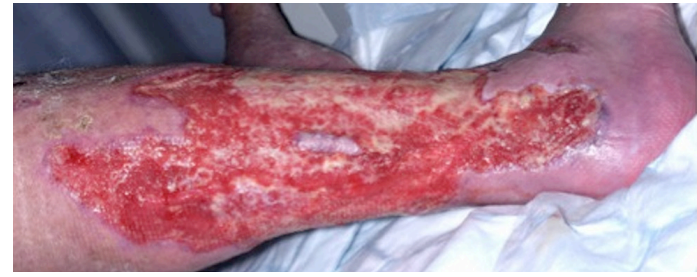

Figure 3 Image showing right leg postbiological maggot debridement therapy.

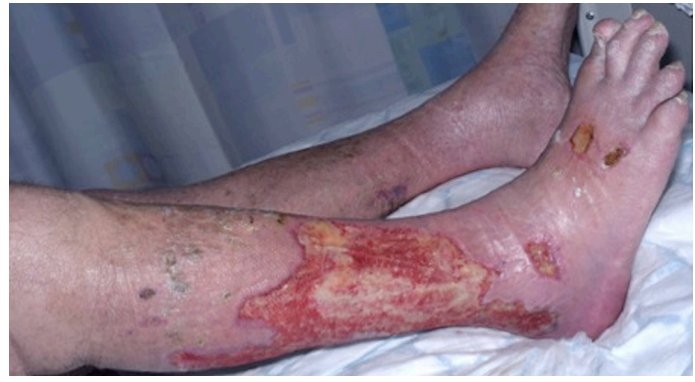

Figure 4 Image showing right leg wound healing prior to discharge.

antibiotic therapy (figure 1). He was an ex-smoker with a medical history of hypertension, atrial fibrillation and previous cerebrovascular event and was treated with intravenous antibiotics for superadded infection. Surgical debridement was undertaken with little success (figure 2). He was offered biological debridement therapy using contained maggots, to which he responded very well and was discharged home after 1 month. (figures 3 and 4 )

Biological debridement uses Green Bottle fly (Lucilia sericata) larvae (figure 5) to remove necrotic tissue and bacteria via proteolytic enzyme secretions. They can be applied free-range or contained. Although there is limited evidence for its use, studies have found the therapy to be safer, quicker and more effective than other debridement

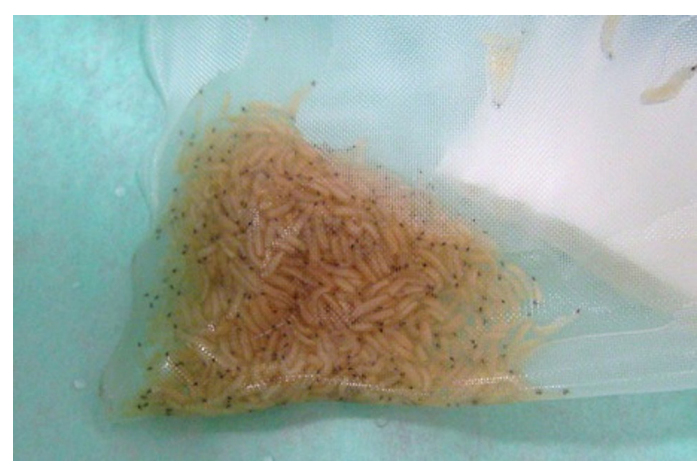

Figure 5 Image of larvae used in biological maggot therapy debridement 


\section{Learning points}

- Biological debridement is a safe and cost-effective debridement method.

- Clinicians are reminded that biological ulcer debridement is an effective option.

- Biological debridement, maggot therapy, should be considered in ulcer care management.

methods. ${ }^{1}$ It has lower amputation rates and faster time for complete debridement when compared with conventional therapies, including hydrogels and/or surgery. ${ }^{2}$ One study found maggot therapy was cheaper, resulted in shorter hospital admissions and faster wound healing, leading to an estimated saving of $£ 50$ million per annum. ${ }^{3}$ Research in biological debridement maggot therapy is limited; however, clinical experience suggests that it is an effective option for debridement and should be considered in the management of ulcer care. ${ }^{4}$
Contributors SM collected the data and drafted the article. AH contributed the data and was reponsible for the critical revision of the article. MJHR was responsible for the conception and critical revision of the article.

Competing interests None declared.

Patient consent Obtained.

Provenance and peer review Not commissioned; externally peer reviewed.

(c) BMJ Publishing Group Ltd (unless otherwise stated in the text of the article) 2017. All rights reserved. No commercial use is permitted unless otherwise expressly granted.

\section{REFERENCES}

1 Gottrup F, Jørgensen B. Maggot debridement: an alternative method for debridement. Eplasty 2011;11:e33.

2 Thomas S. Cost of managing chronic wounds in the UK with particular emphasis on maggot debridement therapy. J Wound Care 2006;15:465-9.

3 Wayman J, Nirojogi V, Walker A, et al. The cost effectiveness of larval therapy in venous ulcers. J Tissue Viability 2000;10:91-4.

4 Morgannwg University Health Board. Magnificent maggots are wonderful wound cleaners. 2012. http://www.wales.nhs.uk/sitesplus/902/news/22870 (accessed 3 May 2017).

Copyright 2017 BMJ Publishing Group. All rights reserved. For permission to reuse any of this content visit

http://group.bmj.com/group/rights-licensing/permissions.

BMJ Case Report Fellows may re-use this article for personal use and teaching without any further permission.

Become a Fellow of BMJ Case Reports today and you can:

- Submit as many cases as you like

- Enjoy fast sympathetic peer review and rapid publication of accepted articles

- Access all the published articles

Re-use any of the published material for personal use and teaching without further permission

For information on Institutional Fellowships contact consortiasales@bmjgroup.com

Visit casereports.bmj.com for more articles like this and to become a Fellow 